\title{
Research on the Current Situation and Countermeasures of Green Finance in Gui'an New District
}

\author{
Chenggang $\mathrm{Li}^{1,2, a}$, Di Wang ${ }^{1, \mathrm{~b}}$, Min $\mathrm{Li}^{1, \mathrm{c}}$ and Kang Pan ${ }^{1 \mathrm{~d}}$ \\ ${ }^{1}$ Faculty of Finance, Guizhou University of Finance and Economics, Guiyang, 550025, P. R. China \\ ${ }^{2}$ Faculty of Science, National University of Singapore, 117546, Singapore \\ a895977948@qq.com, b385954277@qq.com, c2431605045@qq.com,d329223265@qq.com
}

\section{Keywords:Green finance;Development evaluation;Development Strategy}

Abstract. In recent years, green finance has been on the rise in the world. In view of the important position of finance in the development of the contemporary economy and society, especially the green economy, the development of green finance is an effective means to promote the sustainable development of society, economy and environment. It is also an inevitable choice for the healthy development of the future financial industry. Gui'an New District is the only state-level pilot in the western region that is allowed to carry out green finance. Based on the analysis of the basic conditions and key factors of the development of green finance in Gui'an New District. This paper analyzes the current situation of green finance, problems and causes of geen finance development in Gui'an New District, and proposes its development countermeasures.

\section{Introduction}

China has been growing at a high rate since the reform and opening up, and has become the world's second largest economy. However, China's economic development can not avoid the dual constraints of the environment and resources. In 2013, China accounted for $22.4 \%$ of the world's total energy consumption, accounting for $27.1 \%$ of global $\mathrm{CO} 2$ emissions, accounting for only $12.3 \%$ of global GDP. China's energy consumption per unit of GDP is 2.5 times the world average. In 2014, Of the 74 major cities in China, only 8 cities have reached the standard air, and haze became a prominent problem in China's environmental pollution.According to domestic experts estimate that China's environmental pollution costs in recent years account for more than $3 \%$ of GDP ${ }^{[1]}$.Therefore, China put forward the strategy of developing green economy, green finance has gradually emerged.Green finance, also known as environmental finance and sustainable development finance, refers to through the financing, private equity, bonds and stock issuance, insurance, emissions trading and other financial services to introduce social funds into environmental protection, energy saving, clean energy, clean transportation and other green industries a series of policies, institutional arrangements and related infrastructure. In 2017, the State Council of China set Gui'an New District as a green financial reform and innovation pilot area, pointing out the direction for the development of Gui'an New District. Gui'an New District needs government, financial institutions, environmental regulatory authorities and the community to participate in the green industry, and constantly promote the innovation of green financial instruments to make up for funding gaps and promote green financial development.

\section{Analysis on the Problems and Causes of Green Finance Development in Gui'an New District}

Analysis on the Current Situation of Green Finance in Gui'an New District. According to the "Green Credit Guide" promulgated in 2008, China has embarked on the road of green finance development. These policies have promoted the further development and improved China's green finance, and with Jiangsu, Guangdong, Hubei and other regions as a pilot, and achieved some success. In June 2017, the State Council selected Guizhou, Zhejiang, Jiangxi, Guangdong and Xinjiang and other five provinces (regions) as green financial reform and innovation pilot area. Guizhou Province selected the Guinan New Area as a green financial reform innovation pilot area ${ }^{[2]}$. As a result, Gui'an 
New District is the only state-level pilot in the western region that has been allowed to carry out green finance. Guizhou Gui'an New District has become the first batch in the country. It is also the only state-level pilot area in the southwest region that has been allowed to carry out green finance reform and innovation.

At present, the development of green finance in Gui'an New District is relatively backward in theory and practice compared with some developed cities, but Gui'an New District has its unique advantages.First of all, Gui'an New District has advantages in geography, resources and environment, so that Gui'an New District has built industrial structure related to large data. These structures not only conform to the development direction and requirements of green finance, but also the platform to promote green finance. Second, Gui An New District for green finance for a number of financing, the funds will be integrated into the new energy and other projects, and the introduction of the acquisition of financial services companies to support the development of green finance, the establishment of a "green financial port", which has a certain role in promoting the development of green finance in Gui'an New District and laid the foundation for the innovation of green finance theory and practice ${ }^{[4]}$. Analysis on the Development of Green Finance in Gui'an New District. Guiyang new green financial development in an initial stage of development, there are still many problems and shortcomings, in general, due to the following aspects:

First, the development of green finance in Gui'an New District is relatively low compared to other regions. For Gui'an New District, there are still many from the theory to practice the process of transformation. At this stage, although many of the financial institutions in Gui An New District are already trying to do business with green finance, most financial institutions have short-term profitability of green finance as a goal and lack long-term strategic development. This is mainly due to the relatively low level of awareness of green finance by financial institutions, without taking into account the future development and the social responsibility to protect the environment.

Second, financial institutions are not thoroughly understood about the definition of green finance, and the government lacks a complete top-level design. For the meaning and concept of green finance so far can not draw a complete framework and clear content. There are many differences between the top leadership and the actual financial institutions involved in understanding, which leads to a lot of conceptual conflicts between the two sides. In addition, the government departments lack a coordination mechanism and coordination departments to help the government policy to actively implement.

Third, Gui'an New District development of green finance financing is mainly through the green credit. However, green credit is not the best way to finance. Gui'an New District can not be confined to the existing financing methods, the issue of green bonds, green equity financing is the right financing channels, and the current Gui'an New District in the financing channels have yet to be expanded $^{[3]}$.

An Analysis of the Causes of Green Finance Development in Gui'an New District. The main reasons for the problems of green development in Gui'an New District can be attributed to the following:

First of all, Gui'an New Industrial area is small, the industrial structure is irrational.Industrial development scale and industrial structure are the basis of economic development and financial development. As Gui'an New District has just set up only three years, its industrial concentration is too small and the industrial system is not complete. According to statistics, Gui'an New Industrial area is small and the ability to fight against risk is not strong. Therefore, this is not conducive to the development of green finance and green investment and financing in Gui'an New District. In addition, Gui'an New District's industrial development lacks technological innovation. This is because of the geographical location of your new district, relative to the developed areas, Gui'an New District in the industrial development is not an advantage in talent and innovation there is a big enough. This can not provide an industrial base for green finance development, leading to the rapid development of green finance.

Second, the green financial development plan has not yet been established.Although Gui'an New 
District is an important intermediate area in the north and south of Guizhou Province, it has an important hub role and has become a national experimental area for green finance reform and innovation,for Gui'an New District, the development of green finance is still a relatively fresh thing, a lot of things need to run and explore. Gui'an New District as a young national new district, infrastructure construction is not yet perfect. Since its inception, Gui'an New District has taken the infrastructure as a top priority and ignores the development of green economy and green finance. If the government can not raise the green finance to the strategic development level, can not reasonably formulate the green development of the strategic objectives and development plans, Gui' an New District green finance will not be effectively promoted.

Third, Gui'an New District lacks green and financial development policy supporting measures. At present, the green financial policy objective of Gui'an New District is mainly to send green credit to some enterprises, and the green finance of Gui'an New District lacks complete strategy and policy. The various organizations on the core concept of green finance is not thorough understanding, and Guiying new government communication less, there are many cognitive obstacles and conflicts.At the same time, Gui'an New District's understanding of green finance development trends, environmental risk assessment techniques and environmental risk management at home and abroad is not comprehensive.

\section{Countermeasures of Green Finance in Gui'an New District}

\section{Build green financial demonstration area}

Improve the green financial regulation and policy support system. The development of green finance requires good laws and regulations, combined with the actual situation of Gui'an New Economy and environment, perfect and revise green finance laws and regulations, and ensure that laws and regulations are implemented and implemented.Gui'an New District Finance should implement financial subsidies, tax relief and other policies to guide the flow of social funds to green finance, boost the green financial development.

Establish a green and green typical demonstration area, cultivate green financial samples. For financial institutions that are actively developing green finance, the government should incorporate these financial institutions into green financial demonstration zones. For some of the outstanding contributions to environmental protection enterprises, the government should put these enterprises into the green financial demonstration area to cultivate the main object, and give strong support, establish a green finance development of the example, help Guizhou green financial development.

Shaping regional characteristics of financial products and services. New energy and environmental protection industry enterprises have their own financing needs, especially in the early stage of the new energy industry has a huge financial financing needs. Therefore, in the financial product innovation, the government can carry out the future income, pollution charges, patents and other pledge as a new business.

Convenient green credit process and strengthen green credit innovation. For new energy and environmental protection enterprises that meet the national green standards, financial institutions should reduce the threshold of green credit and expand the proportion of green credit in loan. At the same time, strengthen the green credit innovation, and actively cooperate with the government to guide the maximum introduction of social funds flow to the green areas, and provide a strong financial security for green development ${ }^{[5]}$.

Improve the green information sharing mechanism and improve the green financial risk prevention ability. Establish government, financial institutions and environmental protection departments information sharing platform. Accompanied by government guidance, we should combine financial institutions with environmental regulators, and make the integration of new energy and environmental protection industry environmental pollution data and green loan data in Guizhou 
province. Then, put the integrated data into the enterprise credit system for enterprise green finance re-loan reference basis.

Optimize the green assessment standards, increase green financial support. Through the enterprise credit system, environmental protection departments to establish a reasonable assessment criteria. Financial green loan professionals based on the assessment results, the new energy and environmental protection enterprises in line with national requirements, the credit scale can be appropriate to relax the green credit line. For financial institutions with significant performance in green finance, it is possible to relax the rules for the approval of its senior management, the establishment of new bodies and new business approval. To the national standard of new energy and environmental protection enterprises listed on the process, the Commission can set up green channels for such enterprises, indirectly support the development of green finance.

Optimize Green Finance Internal Regulation. For new energy and environmental protection industry enterprises, which meet national standards, financial institutions should implement real-time dynamic monitoring of green credit and monitor all aspects of loans.Credit policy should be differentiated,we should increase support for green credit performance of new energy and environmental protection enterprises, Rationally guide the flow of funds to the green industry, help Guizhou green financial development ${ }^{[6]}$.

Establish green financial investment and financing fund market. In China, with the financial institutions and social capital injection, the establishment of each link in the process have strict standards of implementation. The purpose of the establishment of the Industrial Fund is to promote the growth of new energy and environmental protection industries. As the environmental protection industry has a non-exclusive, non-competitive and external economic characteristics, environmental protection industry development is bound to rely on macroeconomic policy. Therefore, in the new energy and environmental protection industry huge financing capital gap environment, the establishment of government-led green financial market is imminent. First of all,strengthen the government industry-oriented and industrial fund coordination relationship, improve the development of industrial fundswith the green-oriented development. Second, build a platform for the construction of industrial funds laws and regulations, to promote industrial investment funds more stable into the development track. Finally, with Gui'an New District government guidance, financial institutions, environmental protection departments and other social multi-party participation, to make up for the huge demand for industrial funds. New energy and environmental protection industry funds face huge financing funding gap, multi-party participation can be social idle funds to introduce and make up for funding gaps, and promote green economic development.

\section{Acknowledgements}

This work was financially supported by China Scholarship Council.

\section{References}

[1]Industrial and Commercial Bank of China Green Finance Task Force, Yueqiu Zhou, Hong Yin: Research on the Construction of Green Finance Strategy System in Commercial Banks. Financial Forum, Vol. 22 (2017), p. 3-16.

[2]Jun Ma: On the Construction of China 's Green Financial System. Financial Forum, Iss. 5 (2015), p. $18-27$.

[3]Tongyu Wang: Reflections on Promoting the Innovation of Green Financial Mechanis. Macroeconomic Management, Iss. 1 (2014), p. 46-48.

[4]Xiang Deng: A Review of Green Finance Research. Journal of Zhongnan University of Economics and Law, Iss. 6, (2012), p. 67-71.

[5]Renjie Li: Marketization and Green Finance Development.China Finance, Iss. 4 (2014), p. 17-19. 
[6]Jinping Yi, Chun Jiang, Wei Peng: Research on the Present Situation and Countermeasures of Green Finance in China. SAR economy, Iss. 5 (2014), p.81-83. 